\title{
Simulation of the influence of oxygen on the chemical stage of radiobiological mechanism using Petri nets
}

\author{
J Barilla', M Lokajíček², H Pisaková2 ${ }^{*}$, P Simr ${ }^{1}$ \\ From 9th German Conference on Chemoinformatics \\ Fulda, Germany. 10-12 November 2013
}

The radiobiological effect of densely ionizing ends of primary or secondary charged particles may be influenced significantly by processes running in the chemical stage of radiobiological mechanism; especially the influence of present oxygen may be very important. The effect of its or of other species (radiomodifiers) present in water medium during irradiation may be studied with the help of corresponding mathematical models. The model based on the use of Petri nets will be proposed and described.

Two parallel processes, i.e., diffusion of radicals and their chemical reactions, running in corresponding radical clusters formed during energy transfer may be represented with the help of the given model. A great number of chemical species may be easily taken into account. The model enables to study the concentrations of individual radicals changing during cluster diffusion and to estimate their damaging effects on corresponding DNA molecules in given cells. The results demonstrating the influence of oxygen under different concentrations will be presented.

\section{Authors' details}

${ }^{1} \mathrm{~J}$. E. Purkinje University in Usti nad Labem, Faculty of Science, Czech Republic. ${ }^{2}$ Institute of Physics, Academy of Sciences of the Czech Republic.

Published: 11 March 2014

doi:10.1186/1758-2946-6-S1-P12

Cite this article as: Barilla et al: Simulation of the influence of oxygen on the chemical stage of radiobiological mechanism using Petri nets. Journal of Cheminformatics 2014 6(Suppl 1):P12.

${ }^{2}$ Institute of Physics, Academy of Sciences of the Czech Republic Full list of author information is available at the end of the article

Publish with ChemistryCentral and every scientist can read your work free of charge

"Open access provides opportunities to our colleagues in other parts of the globe, by allowing anyone to view the content free of charge."

W. Jeffery Hurst, The Hershey Company.

- available free of charge to the entire scientific community

- peer reviewed and published immediately upon acceptance

- cited in PubMed and archived on PubMed Central

- yours - you keep the copyright

Submit your manuscript here:

http://www.chemistrycentral.com/manuscript/

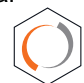

Chemistry Central 